\title{
Correction to: Agent-Based Modelling of Food Production for Water Stewardship: an Overview
}

\section{Huirong $\mathrm{Yu}^{1} \cdot$ Pengfei $\mathrm{Du}^{1}$}

Published online: 10 December 2020

(C) Springer Science+Business Media, LLC, part of Springer Nature 2020

\section{Correction to: Human Ecology}

https://doi.org/10.1007/s10745-020-00197-7

The authors regret that acknowledgment of their funding source was omitted from the manuscript. The original article has been corrected.

Publisher's Note Springer Nature remains neutral with regard to jurisdictional claims in published maps and institutional affiliations.

The online version of the original article can be found at https://doi.org/ 10.1007/s10745-020-00197-7

Pengfei Du

dupf@tsinghua.edu.cn

1 School of Environment, Tsinghua University, Beijing 100084, China 